\title{
Online Visibility, Social Networks and Glamorous Scientific Publications
}

\author{
Carlos Miguel Ferreira ${ }^{1}$, Sandro Serpa ${ }^{2}$ \\ ${ }^{1}$ Polytechnic Institute of Castelo Branco; Estoril Higher Institute for Tourism and Hotel Studies; Interdisciplinary Centre \\ of Social Sciences - CICS.NOVA, Lisbon, Portugal \\ ${ }^{2}$ University of the Azores, Faculty of Social and Human Sciences, Department of Sociology; Interdisciplinary Centre of \\ Social Sciences - CICS.UAc/CICS.NOVA.UAc, and Interdisciplinary Centre for Childhood and Adolescence - NICA - \\ UAc, Ponta Delgada, Azores, Portugal \\ Correspondence: Sandro Serpa, University of the Azores, Faculty of Social and Human Sciences, Department of \\ Sociology.
}

Received: August 16, 2018

Accepted: September 25, 2018

Available online: September 26, 2018

doi:10.11114/ijsss.v6i10.3652

URL: https://doi.org/10.11114/ijsss.v6i10.3652

\begin{abstract}
In a context of transformation of the higher education institutions' mission, there is a growing need for the academy to respond to the needs placed both at the political and social levels, which has implications for the scholar's expected activity. The purpose of this paper is to analyse the growing importance, besides publishing and being cited, of having visibility in the digital world. We conclude that this new dimension, which is being added to the success and legitimacy of the scholar and his/her institution, will have probable direct consequences both on the form and on the contents of future publications. The willingness of scholars to produce publications worthy of social visibility may foster a growing number of publications that are attractive, perhaps less complex and more accessible to the "uninitiated", what we call glamorous publications.
\end{abstract}

Keywords: scientific publication, social visibility, social impact, social attention, academia, Altmetrics

\section{Introduction}

In higher education, the scholar's main functions are to teach, research and publish. It may even be asserted that one of the critical dimensions of the scholar's professional path is the assessment of his/her scientific productivity expressed in publications (quantity and quality), as well as citations of his/her work.

However, we are currently witnessing the reconfiguration of the mission and functioning of higher education institutions, which are imposing on their scholars the use of cognitive maps and the pursuit of action strategies in the institutional field to manage this process. In this context, it seems that a growing social and political pressure to assess the social influence and importance of the action of scholars and their employing institutions begins to emerge with increasing intensity.

One of the main strategies to boost the visibility of the social circulation of scientific knowledge is to focus on cyberspace, namely social networks and blogs, among other virtual environments (Santos \& Serpa, 2017).

On the basis of this assumption, this paper intends to develop a reflection on some possible consequences in the structure and contents of scientific papers themselves, of what we believe is being materialised - the application of bibliometric indicators to assess the social visibility of scientific papers in the digital context.

To this end, we begin by developing a brief analysis of the mission currently assigned to higher education institutions and their scholars. Subsequently, we discuss the importance of publishing and being cited, so as to justify our hypothesis of the growing importance ascribed to the digital social media attention by referring to some alternative metric indicators that seek to account for this dimension. The paper ends with a discussion about the possible influences of this process, either in the research process, or even in the way research will be reported in its final product, focusing our attention on the scientific paper.

\section{Current Mission of Higher Education Institutions and the Scholars' Action}

For a long time, higher education institutions were characterised by insularity, as being too isolated from the society that financed them. However, their impact on society and on the surrounding economy are increasingly valued and scrutinised (Santos, 2016; Müller, 2012; Ravenscroft, Liakata, Clare, \& Duma, 2017), in a re-thinking of their roles besides teaching 
and research (Oertel \& Söll, 2017) - of service to society (Bartholomew, 2017).

The mission and the functioning context of higher education institutions is currently different, albeit there are variations regarding their geographic location and their position in the world-system (Oertel \& Söll, 2017; Wallerstein, 2004). Focusing our attention in Europe: "In a society in which knowledge plays an increasing role, European universities have become essential actors. This has been reflected in demands to redefine their traditional missions and open the door to a 'third mission'. Links with external partners become a central part of its mission and priority of science policy and higher education" (Santos, 2016, p. 107).

In Europe, the mission ascribed to higher education institutions is shifting in the sense that this mission does not only focus on teaching and research, but also on promoting the ability of "creating knowledge and, ultimately, to position itself as a prominent institution that knowledge-based societies and economies are demanding" (Santos, 2016, p. 115).

Several factors act concurrently in this process of transforming the mission of higher education institutions: competition between countries, economic competitiveness, social impact, and financial constraints, in an increasing and permanent political, but also public scrutiny (Santos, 2016; Oertel \& Söll, 2017; Bitetti \& Ferreras, 2017).

This institutional reconfiguration leads to the need of seeking to analyse the social influence of higher education institutions, as well as of each of their scholars individually, considering a certain re-legitimation of their action via their social legitimacy, reputation and visibility, corresponding, to a great extent, to expectations (Oertel \& Söll, 2017). This process is closely linked to the societal dynamics inherent in the high competition for funding, accountability and institutional governance, implying a public process of assessment and an inherent reflection on institutional potentialities and limitations, namely the extent of relationships of interdependence with stakeholders.

\section{To Publish and Be Cited}

A central component of science is communication, which is part of the knowledge construction process. Communication involves three levels: horizontal communication between peers (legitimation); transversal communication between science and society (dissemination); vertical communication between generations (teaching) (Pombo, 2000).

Science works with significant databases and metadata, composed of various formal and informal means of information registration and retrieval, such as books (manuals, dissemination), journals (articles, reviews), theses, research reports, working papers, presentations in congresses, conferences, and teaching. In this process of scientific production and communication, the repositories add to the unrestricted sharing of knowledge produced and to the consolidation of a new paradigm: Open Access (Autran \& Borges, 2014; Gomes, 2013; Tenopir et al., 2016).

The paper is the central formal medium in this process of scientific production and communication, accounting for the scholars' scientific activity, wherein argumentative strategies of persuasion are developed and the interpretative principles privileged by the authors and legitimised by the peers are presented. Several authors claim to be a stylistic fiction that accentuates the traces of objectivity and disinterest by decontextualizing research, requiring a code that is as unambiguous as possible and that aims at building consensus (Amatriaín \& Merlo, 1999; Ziman, 1972).

However, due to scientists' interest in originality, an attitude of non-iteration of scientific work developed by peers is fostered, and scientists generally just determine their consistency, plausibility and utility, and trust in the ethos and integrity of peer-competitors and in the competence and experience of peer reviewers (Amatriaín \& Merlo, 1999).

One of the key elements in the assessment of the functioning of higher education institutions is the importance of publishing and being cited (Hermanowicz, 2016; Bornmann, 2017; Naude \& van Biljon, 2017; Tenopir et al, 2016), both at the institutional level of the academy and at the individual level, in terms of the scholar him/herself.

\section{A. At the institutional level}

The quantity and quality of a higher education institution has always been demonstrated, to a great extent, by its scientific production and R\&D activities, which influence the institution's assessment, attractiveness, media and social image, social legitimacy, and ability to compete for projects, among others.

Currently, there is a need, on the part of higher education institutions, to maximise resources in an increasingly competitive world, demonstrating their quality through educational indicators, but also through clear and objective research and publication indicators (Müller, 2012).

\section{$B$. At the individual level}

The scholar has been essentially defined by his/her ability for teaching and researching, translated into the publication component, implying that "Four themes emerge from these narratives. To publish successfully, academic writers need: (1) to be discourse analysts; (2) to have a critical competence; (3) to have writing fluency; and (4) to be emotionally intelligent" (Badenhorst \& Xu, 2016, p. 1). 
Therefore, scientific productivity, embodied in its dimension of publications, is currently critical in academic life (Cadez, Dimovski, \& Groff, 2015; Tenopir et al., 2016). This scientific productivity is fundamental both at the individual level for academic professional assessment, for employability and even for access to funding resources for research projects, and at the collective level for the prestige and assessment of the institutional quality of higher education and/or research institutions:

Authors employed by academic institutions have at least two important reasons for publishing their research in peer-reviewed journals. On one level, publishing research that has been peer-reviewed is the most common method for an author to establish ownership over an idea and helps build his or her reputation. On another, an author's peer-reviewed publishing record is among the only quantifiable means by which to assess research productivity, as well as the value of his or her contribution to scholarship. Decisions about tenure and promotion, future funding, and even the quality of the author's home academic department are largely based on this peer-reviewed publication record (Tenopir et al., 2016, p. 1).

The pressure to publish is so great that Nygaard (2017) even mentions that

The current discourse on research productivity (how much peer-reviewed academic output is published by faculty) is dominated by quantitative research on individual and institutional traits; implicit assumptions are that academic writing is a predominately cognitive activity, and that lack of productivity represents some kind of deficiency (p. 519) [emphasis added].

Besides a quantitative perspective that focuses on the number of publications, another factor involved in this pressure to publish is the acknowledged quality of the journal where manuscripts are published (considering factors such as the journal's reputation and its indexing) (Imasato, Perlin, \& Borenstein, 2017; Kaba, 2015; Lee, Yap, Lim, \& Tam, 2012; Tenopir et al., 2016; Omer, 2015), as well as the number of citations reached by a particular author/article (Lee et al., 2012).

This takes place in a context in which a model of digital publications is being consolidated, in an open access system, in which the reader has, free of charge and just having access to the Internet, full access to articles published by an increasing number of journals (Miguel, Oliveira, \& Grácio, 2016).

This increasing number of available journals (Imasato et al., 2017) hinders a conscious and informed choice of where to publish. This is because the journals' indexing, being a very important element in the attempt to frame the quality of a journal in a controlled way, besides being many and suffering shifts over time, are not indisputable.

In sum, both journals' indexing and the number of citations attained by an author or an article are important, although there are several calls for attention to the fact that

These large-scale measurements either substitute or supplement evaluation performed by colleagues qualified as specialists in a certain field of research. The so-called citation-indexes count as one among other measurements. And to say it very shortly, the whole idea is that your scientific work is evaluated in accordance with the amount of citations you get from other writers, or in accordance with the citation-impact of the journals in which you publish. This might at first glance seem rather harmless -it might indeed be defended on the ground that it is more objective than the subjective evaluation by peer-reviewers. It is, however, not that harmless. Firstly, because these measurements seem to turn quality into quantity and secondly, because the measurements are used as basis for allocating resources in form of annual budget to an Institute, as well as assigning rewards and securing foundation-money. Thirdly, this development in scientific evaluation may have grave consequences when applied especially to the humanities where in most cases it does not give meaning to evaluate research on a quantitative basis (Gammelgaard, 2016, p. 1).

Despite some issues that may be the target of criticism, "No doubt, bibliometrics has come to stay" (Gammelgaard, 2016, p. 5).

This situation leads to increasing pressure to publish (Silva \& Al-Khatib, 2017), with the dominance of the English language as the lingua franca of science, since it increases the possibility of being cited (Bitetti \& Ferreras, 2017).

This importance of publishing and being cited takes place in a context of the rise of the Open Access publication model, which allows the reader to have immediate and free access to the publication. However, it entails that someone - the author, his/her institution or some sort of funding - takes on the costs (charge or fee) of this publication mode. This model is being built also with political support and is increasingly used, despite the consideration of various aspects and the existence of some weaknesses, such as quality control and who pays for the publication, as well as the existence of salami publications (Burchardt, 2014; Silva \& Al-Khatib, 2017). It seems that this Open Access model will become the dominant model of scientific publishing, notwithstanding deep quality differences between publications (Rae, Hincks, \& 
Stephens, 2017). Hence the importance of using bibliometric indicators in the assessment of scientific production, which we will address hereafter.

The increasing trend towards the use of bibliometric indicators, which generally assess the influence of a given paper in the scientific world for personal, professional and institutional assessment, has consequences in terms of funding, both for the functioning of the institutions and for the submission of applications to funding sources for research projects (Mali, 2013; Gammelgaard, 2016): "The impact by scientists in academia is currently measured by citation based metrics such as h-index, i-index and citation counts. These academic metrics aim to represent the dissemination of knowledge among scientists rather than the impact of the research on the wider world." (Ravenscroft et al., 2017, p. 1). Thus, the measurement of the influence of these publications in the scientific arena is made through the verification of impact indicators, despite their limitations (Konkiel, 2016; Ivan, 2015; Gammelgaard, 2016; Herteliu, Ausloos, Ileanu, Rotundo, \& Andrei, 2017; Fabry \& Fischer, 2017; Lăzăroiu, 2017; Wesel, 2016; Ravenscroft et al., 2017), which is even more evident in the area of social sciences (regarding Sociology, cf. Hermanowicz, 2016; Bornmann, 2017; Franco-Lopez, Sanz-Valero, \& Culebras, 2017).

However, in this new context of pressure and social scrutiny, the social attention given to strategies for the diffusion and dissemination of science in the public space starts being considered in a specific way. That is what we will address in the next section.

\section{Digital Media Social Attention - Altmetrics}

It is undisputed that science is heavily reliant on society as a source of funding (Koohy \& Koohy, 2014), which increases the need to be cited and also to show the impact of each researcher's work (Cress, 2014; Yu, 2017; Chen, 2016), in a context of greater political and social pressure for public scrutiny, in a logic of "demonstrable return-from-investment" (Naude \& van Biljon, 2017).

This happens in a context where scientists continue to struggle to communicate their success and work among the public in general (Smith, 2017).

The digital world has greatly changed the context of action of both institutions and scientists in the way and in the need to communicate (Perovic, 2016; Liu \& Adie, 2013; Smith, 2017).

Looking specifically at digital social networks, they are currently critical at various levels for higher education institutions, such as "to establish trusting relationships with their students and target audience, to strengthen corporate image, to achieve greater recognition, to promote the brand and to improve competitiveness in the sector" (Lacayo-Mendoza \& Pablos-Heredero, 2016, p. 144).

However, at the individual level, the differences in the use of the Internet cannot be forgotten, for example in the use of social network websites among and even within the same generational, gender, socio-professional, ethnic group, etc. for several reasons (Neves \& Rente, 2017; Rambaree \& Knez, 2017; Antheunis, Van den Abelee, \& Kanters, 2015). In an illustrative summary, "A critical use of the Internet can increase access to different forms of capital (e.g., social capital) and resources that allow the user an informed, effective and safe use of the network, while an uncritical use may embody a number of disadvantages for the user, which include the inability to assess the reliability of online information" (Neves \& Rente, 2017, p. 109).

These differences in individual competences also exist, although with specificities in the case of scientists, in the development, in social media, of the impact of each researcher's work (Cress, 2014; Yu, 2017).

The influence and dissemination of science in social digital media is an increasingly important dimension in the aforementioned social scrutiny: "Research councils and investors now expect research scientists to plan for and demonstrate the impact of their work. Attempting to understand and maximise the impact of research should be beneficial to scientists, not only as a requirement of funding, but also because it would help increase our understanding in terms of how scientific findings can benefit human society and the environment" (Ravenscroft et al., 2017, pp. 1-2). This kind of impact beyond academia proves to be "very difficult to detect, understand and measure" (Ravenscroft et al., 2017, p. 2).

There are bibliometric indicators, such as the well-known journal impact factor, that intends to account for the journal's influence in the scientific milieu, focusing on the number of citations (van Leeuwen \& Wouters, 2017). Yet, in addition to presenting limitations (e.g., Moed, 2016; Naude \& van Biljon, 2017; Chen, 2016), such indicators do not account for the dissemination of science in society.

The desire of several actors to measure the social influence of science justifies, in part, the emergence of new indicators for the assessment of researchers and institutions and has motivated forms of assessment of this specific impact that may be designated by "altmetrics" or alternative metrics (Onyancha, 2017; Potter, 2016; Ravenscroft et al., 2017). Some examples of these indicators are Altmetrics, ImpactStory, Plum Analytics and PLOS Metrics (Potter, 2016), which 
generally record the social attention given to a particular paper or any other digital object (Konkiel, 2016; Onyancha, 2017). This social attention can be translated into the sharing of the research piece in digital social networks such as Facebook and Twitter, in comments, likes, tweets, blogs, etc. (both the discussion of technical aspects of alternative metrics and their advantages and limitations fall outside the scope of this paper [Cf. https://www.altmetric.com/ about-altmetrics/what-are-altmetrics/; Fabry \& Fischer, 2017; Potter, 2016]).

Several journals and publishers are incorporating some of these indicators in the assessment of scientific documents (Bornmann, 2017), which is visible from the user's standpoint. This happens - and particularly with Altmetrics - because, to some extent, it is possible to "use Altmetrics to document the societal impact of their published research" (Silva \& Al-Khatib, 2017, p. 67; Konkiel, 2016; https://www.altmetric.com/about-altmetrics/what-are-altmetrics/). Or, also, the very recent information that Scopus will incorporate PlumX Metrics in the sense of "provid[ing] insights into the ways people interact with individual pieces of research output (articles, conference proceedings, book chapters, and many more) in the online environment" (Beatty, 2017).

Yet, we should bear the following call in mind: "Altmetrics can be a reaction to the rising pressure to indicate other kinds of impact and may supply hints of concern from a broader public or some particular publics. The diverse altmetrics can be a sign of distinct degrees of impact" (Lăzăroiu, 2017, p. 310).

These indicators also have weaknesses (Ravenscroft et al., 2017) and are not immune to manipulations: "Altmetrics are also far from immune to manipulation, often without the elaboration required to manipulate citations. Social media can amplify small signals and mass tweets, mentions or likes are easily purchased. The value of a mention can be elusive, mentioners may be anonymous or hidden behind an alias, and heavily mentioned titles often feature quirky titles or other attributes that may not indicate academic merit" (Potter, 2016, p. 71).

However, it should be stressed that there is not necessarily a direct relationship between the impact on online social networks and scientific quality. For example, articles with more provocative or attractive titles may have higher online social impact values, and not due to their intrinsic scientific quality (Poplašen \& Grgić, 2016). Even within the scientific field there are differences, for example, and articles in the scientific area of social sciences, humanities, medical and life sciences tend to have the highest values (Syamili \& Rekha, 2017).

The complementary combination of varied metrics that assess beyond the scientific impact through the number of citations of an article, for example, being aware that what they measure is not the same, emerges as an intrinsic need of rigor in this domain of the kind of individual, but also institutional, impact of the digital scholarly communication (Syamili \& Rekha, 2017; Liu \& Adie, 2013; Poplašen \& Grgić, 2016). Furthermore, there is the need for a quantitative but also a qualitative analysis, in order to have a better understanding of the impact in question, as well as of its reasons (Liu \& Adie, 2013).

\section{Discussion}

The greater "visitability" and social visibility of scientific publications in cyberspace may boost the affirmation, simultaneously, of "scientific culture" as a citizen's right (Gonçalves, 2004), and of a more reflexive conception of science, which has the purpose of analysing critically what it does (its possibilities, its limits, its procedures), so as to assess the conditions under which it does so, as well as the effects of its activity (Costa, 1992). There is a focus on reflexive iteration and the subsequent potentialities of this reflexivity, i.e., the ability of scientists to reflect on themselves and on the cognitive assessments of the "uninitiated", shaped by their different positions in the scientific field, the inherent scientific authority and the search for the maximisation of scientific profit: the attainment of the recognition of peers-competitors (Bourdieu, 1976).

The knowledge and representations that people, groups and societies possess and use, often referred to as "common sense", are, in modern societies, increasingly shaped by the discourses produced by the various sciences. This social appropriation of the knowledge developed by sciences has a return effect by provoking a permanent re-thinking of topics and conceptual elaborations (Almeida, 1994).

All this results in the need to foster scientific literacy, but also media literacy as the ability to access, understand, critically analyse and even produce a message (Perovic, 2016) of a scientific nature also in the digital world (Santos \& Serpa, 2017).

Given this growing relevance of the dissemination and visibility of scientific discourses in social digital media, it seems important to identify, in line with Woolgar (1980), several elements that may enhance the structuring of a scientific text and its reading. A first element regards the preliminary instructions, namely the location in a specific scientific journal, the titles of the paper and the abstract. The location of the paper provides information on the institutional affiliations of the authors and the support obtained for its production. The titles, abstract and epigraphs allow readers to identify the relevant categories and main lines of argument in the text. A second element refers to the externalisation mechanisms, 
which provide the image of the phenomenon under study from the use of certain theoretical and methodological procedures, disavowing any argument that the object under study is the result of the idiosyncrasy of an individual or a specific social group. A third element refers to the driving mechanisms, which allow the identification of previous ways of seeing and doing, giving the reader a framework of the author's current research and options. A fourth element regards the sequencing mechanisms, which allow to order events in the narrative, refusing other potential paths and highlighting other events that are deemed significant (Woolgar, 1980; Espinosa, García, \& Albero, 1994, pp. 562-563).

If this pressure of metric indicators, related to the increasing development of cyberspace, takes on a great centrality, direct effects may occur, both on the form and on the contents of future publications. The search for social visibility may lead to an increasing number of attractive publications, perhaps less complex and more accessible to lay actors. It will involve the tendency to publish papers socially more "saleable": "If altmetrics turn out to be a fashionable standard of academic attainment, as a result a lot of authors will write anything is required to generate attention to their pieces, boosting their altmetrics values and surpassing others. The measure may be excessively straightforward to have any legitimate validity or meaning." (Lăzăroiu, 2017, p. 310). This aspect was already emphasised by Liu and Adie (2013, p. 155), who pointed out, among other subjects, the areas of sexuality, psychoactive drugs and human psychology as examples of topics of "such as "sexier' papers with abnormally high altmetrics". This is what we call, provocatively, glamorous publications.

\section{Acknowledgment}

University of Azores, Interdisciplinary Centre of Social Sciences - CICS.UAc/CICS.NOVA.UAc, UID/SOC/04647/2013, with the financial support of FCT/MEC through national funds and when applicable co-financed by FEDER under the PT2020 Partnership Agreement.

This article is a more refined version of Digital social network e legitimacy. The relevance of social visibility of scientific publications in the digital world, presented in the Conference HASSACC 2017 - From Past to Future with Human and Social Sciences, Section 2.7 - Social Sciences - Past, Nowadays and Future, September 25-29, 2017. The authors thank the conference participants for their valuable comments on this presentation.

\section{References}

Almeida, J. F. (Ed.) (1994). Introdução à sociologia [Introduction to sociology]. Lisboa: Universidade Aberta.

Amatriaín, J., \& Merlo, J. (1999). Sociología del conocimiento científico [Sociology of scientific knowledge]. Madrid: CIS.

Antheunis, M. L., Van den Abeele, M. M. P., \& Kanters, S. (2015). The impact of Facebook use on micro-level social capital: A synthesis. Societies, 5, 399-419. https://doi.org/10.3390/soc5020399

Autran, M. M., \& Borges, M. (2014). Comunicação da ciência: (R)evolução ou crise? [Science communication: (R)evolution or crisis?], RECIIS - Rev. Eletron. de Comun. Inf. Inov. Saúde, 8(2), 122-138.

Badenhorst, C., \& Xu, X. (2016). Academic publishing: Making the implicit explicit. Publications, 4(24), 1-16. https://doi.org/10.3390/publications4030024

Bartholomew, P. (2017). Beyond research productivity: Matching productivity measures to institutional mission. Journal for the Study of Postsecondary and Tertiary Education, 2, 1-11. https://doi.org/10.28945/3559

Beatty, S. (2017). PlumX Metrics now on Scopus: Discover how others interact with your research. Available at https://blog.scopus.com/posts/

plumx-metrics-now-on-scopus-discover-how-others-interact-with-your-research?sf101726331=1． Retrieved on July 31, 2017.

Bitetti, M. S. D., \& Ferreras, J. A. (2017). Publish (in English) or perish: The effect on citation rate of using languages other than English in scientific publications. Ambio, 46, 121-127. https://doi.org/10.1007/s13280-016-0820-7

Bornmann, L. (2017). Measuring impact in research evaluations: A thorough discussion of methods for, effects of and problems with impact measurements. High. Educ., 73, 775-787. https://doi.org/10.1007/s10734-016-9995-x

Bourdieu, P. (1976). Le champ scientifique [The scientific field]. Actes de La Recherche en Sciences Sociales, 2/3, 88-104. https://doi.org/10.3406/arss.1976.3454

Burchardt, J. (2014). Researchers outside APC-financed open access: Implications for scholars without a paying institution. SAGE Open, 1-11. https://doi.org/10.1177/2158244014551714

Cadez, S., Dimovski, V., \& Groff, M. Z. (2015). Research, teaching and performance evaluation in academia: The salience of quality. Studies in Higher Education, 40, 1-19. 
Chen, C. (2016). Grand challenges in measuring and characterizing scholarly impact. Front. Res. Metr. Anal., 1(4), 1-4.

Costa, A. F. (1992). Sociologia [Sociology]. Lisboa: Difusão Cultural.

Cress, P. E. (2014). Using altmetrics and social media to supplement impact factor: maximizing your article's academic and societal impact. Aesthetic Surgery Journal, 34(7), 1123-1126. https://doi.org/10.1177/1090820X14542973

Espinosa, E. L., García, J. M., \& Albero, C. T. (1994). La sociología del conocimiento y de la ciencia [Sociology of knowledge and science]. Madrid: Alianza Editorial.

Fabry, G., \& Fischer, M. R. (2017). Beyond the impact factor - What do alternative metrics have to offer? GMS Journal for Medical Education, 34(2), 1-8.

Franco-López, A., Sanz-Valero, J., \& Culebras, J. M. (2017). Impact factor is no longer the gold standard; the San Francisco declaration on research assessment. Journal of Negative \& No Positive Results, 2(5), 173-176.

Gammelgaard, J. (2016). Citation and the hidden authority. International Journal of Social Science Studies, 4(12), 1-5. https://doi.org/10.11114/ijsss.v4i12.1956

Gomes, C. (2013). Comunicação científica: Alicerces, transformações e tendências [Scientific communication: Foundations, transformations and trends]. Covilhã: UBI, LabCom, Livros LabCom.

Gonçalves, C. D. (2004). Cientistas e leigos: Uma questão de comunicação e cultura [Scientists and lay: A matter of communication and culture]. Comunicação e Sociedade, 6, 11-33. https://doi.org/10.17231/comsoc.6(2004).1226

Hermanowicz, J. C. (2016). The proliferation of publishing: Economic rationality and ritualized productivity in a neoliberal era. Am. Soc., 47, 174-191. https://doi.org/10.1007/s12108-015-9285-6

Herteliu, C., Ausloos, M., Ileanu, B. V., Rotundo, G, \& Andrei, T. (2017). Quantitative and qualitative analysis of editor behavior through potentially coercive citations. Publications, 5(15), 1-16. https://doi.org/10.3390/publications5020015

Imasato, T., Perlin, M. S., \& Borenstein, D. (2017). Análise do perfil dos acadêmicos e de suas publicações científicas em administração [An analysis of academics and their scientific publications in the field of management]. RAC, 2l(1), $62-83$.

Ivan, S. (2015). Analysis of bibliometric indicators to determine citation bias. Palgrave Communications, 1, 15011. https://doi.org/10.1057/palcomms.2015.11

Kaba, A. J. (2015). Contributors to the American Sociological Review, 2010. Sociology Mind, 5, 114-146. https://doi.org/10.4236/sm.2015.52012

Konkiel, S. (2016). Altmetrics: Diversifying the understanding of influential scholarship. Palgrave Communications, 2, 16057. https://doi.org/10.1057/palcomms.2016.57

Koohy, H., \& Koohy, B. (2014). A lesson from the ice bucket challenge: Using social networks to publicize science. Front. Genet., 5, 430. https://doi.org/10.3389/fgene.2014.00430

Lacayo-Mendoza, A., \& Pablos-Heredero, C. (2016). Managing relationships and communications in higher education efficiently through digital social networks: The importance of the relational coordination model. DYNA, 83(195), 138-146. https://doi.org/10.15446/dyna.v83n195.49296

Lăzăroiu, G. (2017). What do altmetrics measure? Maybe the broader impact of research on society. Educational Philosophy and Theory, 49(4), 309-311. https://doi.org/10.1080/00131857.2016.1237735

Lee, T. H., Yap, C. S., Lim, Y. M., \& Tam, C. L. (2012). Accounting researchers in Asia Pacific: A study on publication productivity and citation analysis. Asian Journal of Finance \& Accounting, 4(1), 132-150.

Liu, J., \& Adie, E. (2013). New perspectives on article-level metrics: Developing ways to assess research uptake and impact online. Insights, 27(2), 153-158. https://doi.org/10.1629/2048-7754.79

Mali, F. (2013). Why an unbiased external R\&D evaluation system is important for the progress of social sciences - The case of a small social science sommunity. Soc. Sci., 2, 284-297. https://doi.org/10.3390/socsci2040284

Miguel, S., Oliveira, E. F. T., \& Grácio, M. C. C. (2016). Scientific production on open access: A worldwide bibliometric analysis in the academic and scientific context. Publications, 4(1), 1-15. https://doi.org/10.3390/publications4010001

Moed, H. F. (2016). Toward new indicators of a journal's manuscript peer review process. Front. Res. Metr. Anal., 1(5).

Müller, H. (2012). Towards objectivity in rankings: Using citation data to assess the research performance of higher education institutions. Journal of the World Universities Forum, 5(2), 49-58. 
Naude, F., \& van Biljon, J. (2017). Scholarly impact: A bibliometrics and altmetric study of the Journal of Community Informatics. The Journal of Community Informatics, 13(1), 15-175.

Neves, B. B., \& Rente, R. (2017). Não alinhados? Jovens não utilizadores de sites de redes sociais. Uma abordagem weberiana [Non-aligned? Young non-users of social network sites. A weberian approach]. Sociologia, Problemas e Práticas, 85, 107-129.

Nygaard, L. P. (2017). Publishing and perishing: An academic literacies framework for investigating research productivity. Studies in Higher Education, 42(3), 519-532. https://doi.org/10.1080/03075079.2015.1058351

Oertel, S., \& Söll, M. (2017). Universities between traditional forces and modern demands: The role of imprinting on the missions of German universities. High. Educ., 73, 1-18. https://doi.org/10.1007/s10734-016-0013-0

Omer, R. A. (2015). International scientific publication in ISI journals: Chances and obstacles. World Journal of Education, 5(6), 81-90. https://doi.org/10.5430/wje.v5n6p81

Onyancha, O. B. (2017). Altmetrics of South African journals: Implications for scholarly impact of South African research. Pub. Res. Q., 33, 71-91. https://doi.org/10.1007/s12109-016-9485-0

Perovic, J. (2016). Towards a new, digital communication paradigm. Studies in Media and Communication, 4(1), 99-110. https://doi.org/10.11114/smc.v4i1.1592

Pombo, O. (2000). Comunicação e construção do conhecimento [Communication and knowledge construction] (reprint in O. Valente (Ed.), Itinerários. Investigar em Educação [Itineraries. Research in Education] (pp. 755-760). Lisboa: CIE.

Poplašen, L. M., \& Grgić, I. H. (2016). Altmetric and bibliometric scores: Does open access matter? Qualitative and Quantitative Methods in Libraries, 5, 451-460.

Potter, I. (2016). Beyond the impact factor: Taking a wider view of journal evaluation. Insights, 29(1), 70-77. https://doi.org/10.1629/uksg.287

Rae, A., Hincks, S., \& Stephens, H. (2017). The role of open access in a changing academy: Reflections on a new publishing paradigma. Regional Studies, Regional Science, 4(1), 42-48. https://doi.org/10.1080/21681376.2017.1308063

Rambaree, K., \& Knez, I. (2017). Young people's identity \& Facebook behaviour: The role of gender and ethnicity. Cogent Social Sciences, 3. https://doi.org/10.1080/23311886.2017.1359895

Ravenscroft, J., Liakata, M., Clare, A., \& Duma, D. (2017). Measuring scientific impact beyond academia: An assessment of existing impact metrics and proposed improvements. PLoS ONE, 12(3), 1-21e0173152. https://doi.org/10.1371/journal.pone.0173152

Santos, A. I., \& Serpa, S. (2017). The importance of promoting digital literacy in higher education. International Journal of Social Sciences Studies, 5(6), 90-93. https://doi.org/10.11114/ijsss.v5i6.2330

Santos, P. (2016). Moving the universities to the «third mission» in Europe. New impulses and challenges in doctoral education. Foro de Educación, 14(21), 107-132. https://doi.org/10.14516/fde.2016.014.021.006

Silva, J. A., \& Al-Khatib, A. (2017). Threats to the survival of the author-pays-journal to publish model. Pub. Res. Q., 33, 64-70. https://doi.org/10.1007/s12109-016-9486-Z

Smith, D. R. (2017). Confessions of a science blogaholic: Highs, lows, and increasing liabilities. Front. Commun., l(15), 1-6. https://doi.org/10.3389/fcomm.2016.00015

Syamili, C., \& Rekha, R. V. (2017). Do altmetric correlate with citation? A study based on PLOS ONE journal. COLLNET Journal of Scientometrics and Information Management, 11(1), 103-117. https://doi.org/10.1080/09737766.2016.1260815

Tenopir, C., Dalton, E., Fish, A., Christian, L., Jones, M., \& Smith, M. (2016). What motivates authors of scholarly articles? The importance of journal attributes and potential audience on publication choice. Publications, 4, 1-22. https://doi.org/10.3390/publications4030022

van Leeuwen, T. N., \& Wouters, P. F. (2017). Analysis of publications on journal impact factor over time. Front. Res. Metr. Anal., 2(4).

Wallerstein, I. (2004). World-systems analysis: An introduction. Durham: Duke University Press.

Wesel, M. van (2016). Evaluation by citation: Trends in publication behavior, evaluation criteria, and the strive for high impact publications. Sci. Eng. Ethics, 22, 199-225. https://doi.org/10.1007/s11948-015-9638-0 
Woolgar, S. (1980). Discovery: Logic and sequence in a scientific text. In K. Knorr, W. Krohn, \& R. Whitley (Eds.), The social process of scientific investigation. Sociology of the sciences yearbook, IV (pp. 239-268). Dordrecht: Reidel.

$\mathrm{Yu}, \mathrm{H}$. (2017). Context of altmetrics data matters: An investigation of count type and user category. Scientometrics, 111, 267-283. https://doi.org/10.1007/s11192-017-2251-z

Ziman, J. (1972). El conocimiento público [Public knowledge]. Mexico: Fondo de Cultura Económica.

\section{Copyrights}

Copyright for this article is retained by the author(s), with first publication rights granted to the journal.

This is an open-access article distributed under the terms and conditions of the Creative Commons Attribution license which permits unrestricted use, distribution, and reproduction in any medium, provided the original work is properly cited. 